\title{
sciendo
}

\section{Connecting the Dots: Exploring the Knowledge-based Antecedents of SMEs' Profitability and Development via International Ventures}

\author{
Andreia Gabriela ANDREI \\ Alexandru Ioan Cuza University of Iasi, Iasi, Romania \\ Violeta-Mihaela DINCĂ \\ Bucharest University of Economic Studies, Bucharest, Romania \\ Andreea MITAN \\ National University of Political Studies and Public Administration, Bucharest, Romania \\ Elena-Mădălina VĂTĂMĂNESCU \\ National University of Political Studies and Public Administration, Bucharest, Romania \\ madalina.vatamanescu@facultateademanagement.ro
}

\begin{abstract}
As shifts occur on the global market and business models adapt to a dynamic environment, the process of business internationalization, as performed by small and medium-sized enterprises (SMEs), maintains its relevance for academics, professionals, international organizations, and authorities. Studies in the field have emphasized the strategic component of internationalization, linking it to cultivating (sustainable) competitive advantages, to stimulating strategic innovation, to the pursuit of profitability, and to an overall improved performance, taking into account the activities conducted on foreign markets. Based on a survey carried out with over 100 European SMEs in the steel field, this study examines the influences of strategic collaborators (from international business networks), intermediaries (as organizational links to the target stakeholders), and strategic innovation on SMEs' profitability resulted from international operations, and on the level of business development on foreign markets. The results have shown positive influences among most of the considered factors (i.e., direct collaborators, strategic innovation, international profitability and development), whereas intermediaries have a significant influence only on international profitability and not on SMEs' development on foreign markets.
\end{abstract}

Keywords: internationalization, small and medium-sized enterprises (SMEs), strategic innovation, collaborators, intermediaries, profitability, development, knowledge.

Please cite the article as follows: Andrei, A. G., Dincă, V.M., Mitan, A., Vătămănescu, E. M. (2021), "Connecting the Dots: Exploring the Knowledge-based Antecedents of SMEs' Profitability and Development via International Ventures", Management \& Marketing. Challenges for the Knowledge Society, Vol. 16, No. 3, pp. 167-186, DOI: 10.2478/mmcks-2021-0011. 


\section{Introduction}

In a rather tumultuous global economy, where developments are marked by unpredictability and imbalances (Cegarra-Navarro et al., 2021; Klein and Todesco, 2021), many small and medium sized companies (SMEs) that envision foreign market expansion and gaining profits via international ventures lean towards entering strategic partnerships and engaging in knowledge-sharing practices with trusted collaborators, in order to systematically innovate and be able to maintain relevance on international markets (Vătămănescu et al., 2016a; Raza-Ullah and Eriksson, 2017; Gomezel and Rangus, 2018; Vătămănescu et al., 2021).

Numerous enterprises choose a gradual internationalization process (Bell, McNaughton, Young and Crick, 2003; Cavusgil and Knight, 2009; Johanson and Vahlne, 2009; Vătămănescu, Alexandru and Gorgos, 2014; Vătămănescu, Alexandru and Andrei, 2015) and tend to follow a certain pattern: they begin by exporting products, usually in an uneven and inconstant manner, choosing as a destination convenient markets that they already know, then they progress towards using agents or intermediaries for international trade, and only after attaining a certain level of success, they establish a foreign branch (Luostarinen and Gabrielsson, 2006). The pace at which gradual internationalization happens depends upon variables such as access to know-how, means and funds (SotoAcosta et al., 2016; Sindakis, Aggarwal and Theodorou, 2017).

This step-by-step SMEs internationalization process is many times hindered by the lack of capital, lack of adequate public support, lack of proper knowledge and information, by the high cost or by the difficulties related to the administrative procedures necessary for transportation, by laws and regulations in force in the foreign country, by customs duties or other obstacles to trade in the foreign market, or by cultural differences, including the commercial culture (Nguyen and Le, 2019). Other studies (Senik et al., 2011; Dolfsma and van der Eijk, 2016) list even more barriers, such as the price of their product or service, the high cost of internationalization, the quality of the product and the lack of qualified staff, the specifications of the company's products, and even the language. Insufficient material and financial assets, having to face a lack of managerial competence and know-how in international settings, as well as not being able to adopt a proactive attitude towards internationalization have also been shown to pose difficulties to SMEs that seek to thrive outside the domestic market (Frazier et al., 2009; Vătămănescu, Gorgos and Alexandru, 2018; Vătămănescu and Mitan, 2019). In situations as such, joining relevant business networks, and engaging in informal cooperation, which may trigger innovative organizational structures with new knowledge-based competencies (Bratianu, Hadad and Bejinaru, 2020; Bratianu, Prelipcean and Bejinaru, 2020; Giannacourou et al., 2015), are means to support the internationalization process, that SMEs may choose to adopt. And while the step-by-step internationalization process has long been studied, the network approach has gained impressive momentum lately.

Corroborating the various facets of SMEs internationalization process, which range from fostering strong relationships with strategic partners in business networks and resorting to intermediaries or pursuing strategic innovation, the current paper aims to tackle the knowledge-based antecedents of SMEs' attainment of a high level of profitability and development via international ventures. To this end, the endeavor responds to an existing knowledge gap - also highlighted by Vătămănescu et al. (2019a,b, 2020a,b, 2021) that is, the research on the pivotal factors of SMEs internationalization is still calling for 
further exploration. Therefore, this paper puts the internationalization specificity in the spotlight via an exploratory undertaking. The main objective of the study is to connect the dots by the simultaneous investigation of the impact of the key knowledge-based antecedents of SMEs' international ventures, namely: direct collaborators, intermediaries, and strategic innovation, on the two critical outcomes of the internationalization process: SME's development on the foreign markets, and the profitability achieved through international operations. To support this goal, the study was structured as follows: the literature review and hypotheses development are presented. Next, the materials and method are briefly described with a view to account for the unfolding of the empirical investigation and results. The last section comprises the discussion of the findings and the conclusions of the paper, proposing future research avenues.

\section{Literature review}

Cooperation with various bodies and organizations, strategic collaborators from international business networks or intermediaries is now considered highly supportive to small and medium-sized enterprises (SMEs) that plan on international expansion. Understanding the business environment, identifying the key actors, choosing the appropriate partners and collaborators and establishing trust-based relationships (Vătămănescu et al., 2016b, 2017; Vătămănescu et al., 2020a,b,c, 2021) are essential to business development on foreign markets, as the lack of resources, as well as unexpected unfavorable interactions with third parties, may impede the company from reaching its goals (Hossain, Azam and Quaddus, 2021).

SMEs, especially small companies at the beginning of their internationalization process, are motivated to form durable ties with other companies. They tend to build-up trust-based collaborations gained as a result of integrating rational, emotional and spiritual knowledge when choosing to partner (Bratianu et al., 2021). Engaging in strategic international partnerships, in order to overcome financial burdens and their liability of newness and smallness, to gain brand notoriety and trust, are almost universal reasons for which SMEs decide to forge strong ties to foreign partners (Capik and Brockerhoff, 2017).

Smaller firms engage into strategic international partnerships in order to take advantage of a faster entrance on a foreign market, and to fulfill economies of scale (Van Gils and Zwart, 2009, Andrei and Zait, 2014). Small companies gain, through a quicker market entry, in partnership with international or foreign strategic collaborators, the benefit of having to face lower uncertainties, as well as dispensing them among partners (Swoboda, Meierer, Foscht and Morschett, 2011; Nistoreanu, Dincă and Șchiopu, 2017). Access to a wider array of social, technical, financial, and commercial competitive means and tools has been listed as another highly regarded benefit of signing into strategic international collaborations (Varis et al., 2005; Dima and Vasilache, 2015). This sort of collaborations also supports small companies through knowledge sharing on client and rival companies (Capik and Brockerhoff, 2017), and by stimulating corporate learning and progress (Comi and Eppler, 2009; Dima and Vasilache, 2009).

Strategic international collaborations, especially for SMEs that are part of a network, allow these companies to seize many market opportunities, facilitate access to information, speed up the information transmission, and offer a valuable tool in reputation building (Håkansson et al., 2009). Studies show that SMEs that aim at performing well on foreign markets also benefit from collaboration with members of informal knowledge networks, 
which provide assistance in obtaining business advice from foreign trade experts, help in identifying business opportunities, and support learning from peers through sharing experiences (Abrahamsen et al., 2016; Dima and Ghinea, 2016; Keszey, 2018).

The ideas formulated above ascertain the framing of the following two hypotheses:

H1: Strategic collaborators have a positive influence on SMEs' development on foreign markets.

H2: Strategic collaborators have a positive influence on SMEs' profitability achieved through international operations.

Strategic international collaborations or alliances are vital compounds of the SMEs` strategy, and they evolve over time, to respond to the imperative of maintaining relevance and the competitive position on foreign markets (Elmuti and Kathawala, 2001; Swoboda, Pop and Dabija, 2010; Wassmer, 2010; Raza-Ullah and Eriksson, 2017). Joining forces with other SMEs as part of strategic collaborations has been proven to have a supportive effect on innovative performance (Möller and Rajala, 2007). While strategic collaboration with foreign partners is stimulated by the need to survive and adapt to a competitive environment (Fredrich, Bouncken and Kraus, 2019), the usual outcome of such collaborations is a significant increase in innovation at multiple levels, and an improvement in the practices of the firm (Miller and Friesen, 1982).

Strategic partnerships with international SMEs are propelling factors for increased innovative performance (Raposo, Ferreira and Fernandes, 2014; Vătămănescu et al., 2020a,b). And when SMEs choose to cooperate with research organizations, intermediaries, and other SMEs, with the purpose to foster strategic innovation, the overall performance level of the company can only increase (Zeng, Xie and Tam, 2010; Sindakis, Aggarwal and Chen, 2017, 2019).

There is empirical evidence that companies that innovate are more profitable than those who do not, but innovations themselves only offer transitory competitive advantages (Roberts, 1999; Cefis and Ciccarelli, 2005; Love et al., 2009). The profitability increase due to innovation is especially strong in sectors in which the companies are able to appropriate the results of their own R\&D pursuits that produce innovative results (Hanel and St-Pierre, 2002). In any case, the market position plays a significant role in allowing the innovative company to draw long-term profits from its innovative products, and that is because the company is then able to introduce multiple innovations at a time and is able to protect these products from being copied by the competitors (Geroski et al., 1993; Leiponen, 2000). Innovative activity does not self-sustain, meaning that companies do not tend to innovate over long periods (Geroski et al., 1997), but manage to keep abreast by engaging in strategic collaboration with other companies that invest in R\&D (Bustinza, Gomes, Vendrell-Herrero and Baines, 2019).

Innovation is not a per-se goal of SMEs that seek to perform on international markets, but it prompts superior value creation that leads to profits, and strong inter-firm alliances or partnerships deliver to this end, mainly by pooling members' competences, sharing information and harnessing knowledge to innovate (Sampson, 2007; Andrade Rojas et al., 2018; Vătămănescu et al., 2020d). International collaborations are purposeful, and SMEs do select those partners that can best further their agendas. For example, when an SME cultivates relationships with companies that occupy central positions within the intrasector or cross-sector network, direct knowledge sharing becomes a tool to signal that the 
company has a good grasp on the market, and that it is eager to innovate (Castela et al., 2018; Jordão, Novas and Gupta, 2019).

Building a strong relationship with a single strategic partner instead of building weaker links to various members of a network has been pointed out as being a source of building a faster network position on a foreign market (Małys and Fonfara, 2019). Even collaboration with rivals from the same network (coopetition) leads, under certain circumstances, to remarkable profits, because this stimulates the company to use more wisely the skills that they already have, and to acquire new technological skills from their partners (Quintana-García and Benavides-Velasco, 2004; Vătămănescu et al., 2021) or to develop distinctive competencies (Luo, 2007; Vătămănescu \& Alexandru, 2018).

Overall, strategic collaborations with foreign partners impact SMEs` position on international markets through enhanced knowledge sharing, all the more in those cases when foreign employees are shared, when the foreign input is significant, and when sales on foreign markets are considered a priority (Iturrioz, Aragon \& Narvaiza, 2015; Alexandru et al., 2020; Bratianu et al., 2020, 2021; Demirbag et al., 2021).

Therefore, the following hypotheses are proposed:

H3: Strategic collaborators have a positive influence on SMEs' strategic innovation. markets.

H4: Strategic innovation has a positive influence on SMEs' development on foreign

H5: Strategic innovation has a positive influence on SMEs' profitability achieved through international operations.

The beneficial effects that collaboration has on the internationalizing SMEs are numerous and range from an increase in the SMEs' performance, to supporting international expansion and an increase in profits (Efrata and Øynab, 2020). Other SMEs in the same field or in complementary fields, both from their country of origin and from other countries, members of professional business networks, government authorities and regulating bodies, and informal organizations, like community interest companies, are relevant collaborators to companies that work towards reaching international success and profits (Vătămănescu et al., 2019a,b). And while all collaborators might prove noteworthy, SMEs that aim at establishing their presence on a foreign market and maximizing their profits benefit to a high extent from developing relationships with high level intermediaries, from companies to decision makers and politicians. Some business environments are specifically tailored to support this practice: the guanxi system in China, the yongo system in Korea, and the jinmyaku system in Japan are standing examples (Li et al, 2019).

Collaborating with innovation intermediaries facilitate organizational performance by performing co-creative activities, which lead to co-development (Howells, 2006; Boon et al., 2011). These companies play a central role in a network, creating more links for a company, mediating relationships, bridging knowledge and capability gaps with the purpose of generating value, direct financial benefits, and also non-financial benefits for all companies involved (Smedlund, 2006; Klerkx and Leeuwis, 2008a; Klerkx and Leeuwis, 2008b; Sieg et al., 2010; Huizingh, 2011; Tran et al., 2011; Landry et al., 2013; Knockaert and Spithoven, 2014; Edler and Yeow, 2016). Non-financial benefits refer to social capital and knowledge, which also further the process of product development (Earl, 2001), better grasp on technology, or intellectual property (Martín-de Castro, 2015), and an overall better capability to work together with partners on a technological or market level 
(Lichtenthaler and Ernst, 2008; Nell and Lichtenthaler, 2011; Lichtenthaler, 2013; Melle and Russo-Spena, 2015). Innovation intermediaries support knowledge capitalisation and significantly influence market value creation, proving that working with innovation intermediaries and/or establishing strong network ties lead to creating products and services that are highly marketable, and generate profits for all actors involved, including the innovation intermediaries, who also further knowledge this way (De Silva, Howell and Meyera, 2018).

The intermediaries, in general, act as supportive forces to the expansion of the SME to external markets and facilitate the increase of profits through a multitude of means: they may provide information about the market and insight regarding the business ecosystem, they may act as door-openers to SMEs that are otherwise considered newcomers, and offer invaluable insidership supply to foreign SMEs (Apaydin, Thornberry and Sidani, 2020), they may connect buyers with sellers, they may identify buyers, and they may negotiate terms of trade and importing/ exporting activities (Dekel-Sachs et al., 2021). For SMEs that are working towards international expansion through exports/ imports, intermediaries play a significant role in fostering international trade. The impact of intermediaries is rather important, as, for example, around 50\% of imports to US from China come through firms classified as wholesalers or mixed firms, while around 35\% of the imports to Italy (20152020 ) were conducted by intermediaries (World Bank, 2020), and 32\% of the exports from France to other countries in 2020 were performed by intermediaries (European Commission, 2021). Even the association with an informal network of local merchants, such as a bazaar, has been noted to have a positive impact on the economic performance and profit of an international subsidiary (Apaydin, 2020). Based on these arguments, the following hypotheses emerge:

H6: Intermediaries have a positive influence on SMEs' development on foreign markets.

H7: Intermediaries have a positive influence on SMEs' profitability achieved through international operations.

Corroborating the abovementioned hypotheses, the following research model was advanced (Figure 1):

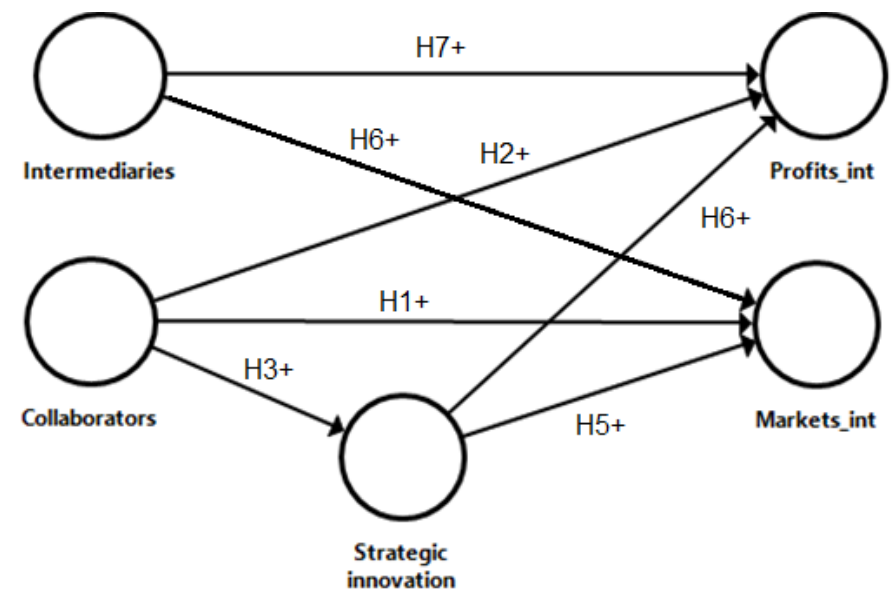

Figure 1. Inferred relationships 


\section{Materials and method}

A multi-section online questionnaire was applied in 2019 (from early June to the end of August) on a convenience sample comprising European small and medium-sized enterprises operating in the steel industry whose top managers (aged 35-55, postgraduate studies, over 5 years in the actual position) agreed to participate in the study (about a quarter of those invited).

The snowball sampling was applied, and the invitations to participate in the study were distributed to a list of over 400 steel industry contacts comprising top managers of the European SMEs, which are active on the international markets. About a quarter of the managers invited to participate in the study have responded, most of them (102 participants) matching our filtering criteria (i.e., participant's experience and SME's affiliation to strategic networks). Thus, the resulted size of the research sample was $\mathrm{N}=102$, representing the number of participants whose questionnaires were considered for analysis.

The questionnaire respondents (35-55 years old, postgraduate studies, over 5 years in the actual position, top managers of a steel industry SME affiliated to the strategic networks in the field, and activating on the international markets) representing companies from sixteen European countries (Croatia, Estonia, France, Germany, Hungary, Ireland, Italy, the Netherlands, Poland, Romania, Serbia, Spain, Switzerland, Turkey, UK, Ukraine) filled in a multi-section survey comprising more than 100 items related to strategic and operational aspects of SMEs strategic approaches on pivotal processes and outcomes, such as business partnerships, collaborations, innovation and internationalization.

The participants' responses (measured on a Likert scale that ranged from 1 to 7) were appraised from different angles (i.e., related to various research foci), while the findings were reported in different works, each of them addressing interconnected, yet distinctive facets and conceptual dimensions.

This study complements the previous works, reporting the investigation of SMEs' development on external markets (Markets_int variable) and the profitability achieved through international operations (Profits_int variable), in relation to the use of intermediaries - as exports facilitators, and the development of strategic collaborations on foreign markets - both as innovation and internationalization drivers.

Placing direct collaborations and the usage of intermediaries under the same lens, the investigation aimed to allow the simultaneous assessment of their influence on internationalization facets, namely expansion and profitability.

Therefore, this study focused on the relationships between five research variables (measurements reliability and the detailed items are presented in Table 1), and the objective of the investigation was to assess the impact of Intermediaries, Collaborators, and Strategic Innovation variables on the dependent variables Markets_int and Profits_int.

Table 1. Research variables

\begin{tabular}{|l|l|l|}
\hline Variables & Measurement items and reliability & References \\
\hline Intermediaries & Reflective with 7 items (Cronbach's Alpha = 0.952): & Lichtenthaler \\
& To what extent, the company (in its internationalization efforts) has & (2013); \\
& resorted to an intermediary in order to: & Li et al, (019); \\
& 1. acquire new information & Apaydin, \\
& 2. gain important insights about business opportunities & Thornberry \\
& 3. endorsed in order to be entrusted important business information & and Sidani \\
\hline
\end{tabular}




\begin{tabular}{|c|c|c|}
\hline & $\begin{array}{l}\text { from a new collaborator } \\
\text { 4. establish new collaborations on a foreign market } \\
\text { 5. develop sustainable collaborations on a foreign market } \\
\text { 6. strengthen a certain collaboration on a foreign market } \\
\text { 7. get the facilitation of some important business discussions with other } \\
\text { firms } \\
\text { (ratings from } 1 \text { = "not at all" to } 7 \text { "very much") }\end{array}$ & $\begin{array}{l}\text { (2020); } \\
\text { Dekel-Sachs et } \\
\text { al. (2021) }\end{array}$ \\
\hline Collaborators & $\begin{array}{l}\text { Single-item: } \\
\text { The number of direct international collaborators which are important } \\
\text { for your business competitiveness } \\
\text { (ratings from } 1=\text { "less than } 5 \text { " to } 7 \text { = "more than } 50^{\circ} \text { ) }\end{array}$ & $\begin{array}{l}\text { Vătămănescu } \\
\text { et al. (2016a,b, } \\
\text { 2017) }\end{array}$ \\
\hline $\begin{array}{l}\text { Strategic } \\
\text { innovation }\end{array}$ & $\begin{array}{l}\text { Single-item: } \\
\text { To what extent is the company's innovative performance in } 2018 \text { a } \\
\text { result of joining strategic business networks? } \\
\text { (ratings from } 1=\text { "less than } 10 \% \text { " to } 7=\text { "more than } 90 \% " \text { ) }\end{array}$ & $\begin{array}{l}\text { Vătămănescu } \\
\text { \& Alexandru } \\
\text { (2018) }\end{array}$ \\
\hline Markets_int & $\begin{array}{l}\text { Single-item: } \\
\text { On how many international markets is the organization present at the } \\
\text { moment (through export, joint ventures, foreign investments, etc.)? } \\
\text { (ratings from } 1=\text { "less than } 5 \text { " to } 7=\text { "more than } 50^{\prime} \text { ) }\end{array}$ & $\begin{array}{l}\text { Vătămănescu } \\
\text { et al. (2021) }\end{array}$ \\
\hline Profits_int & $\begin{array}{l}\text { Single-item: } \\
\text { To what extent is the company's profit in } 2018 \text { a result of international } \\
\text { operations (import, export, distribution etc.)? } \\
\text { (ratings from } 1=\text { "less than } 10 \% \text { " to } 7=\text { "more than } 90 \% " \text { ) }\end{array}$ & $\begin{array}{l}\text { Vătămănescu } \\
\text { et al. } \\
(2019 a, b)\end{array}$ \\
\hline
\end{tabular}

Source: Authors' own research results

The analysis of the data was performed using SPSS software, and the relationships between the investigated variables were tested using regression analysis (the detailed results are presented in the following section), the influences with statistical significance at $\mathrm{p}<0.05$ level being outlined in Figure 2 .

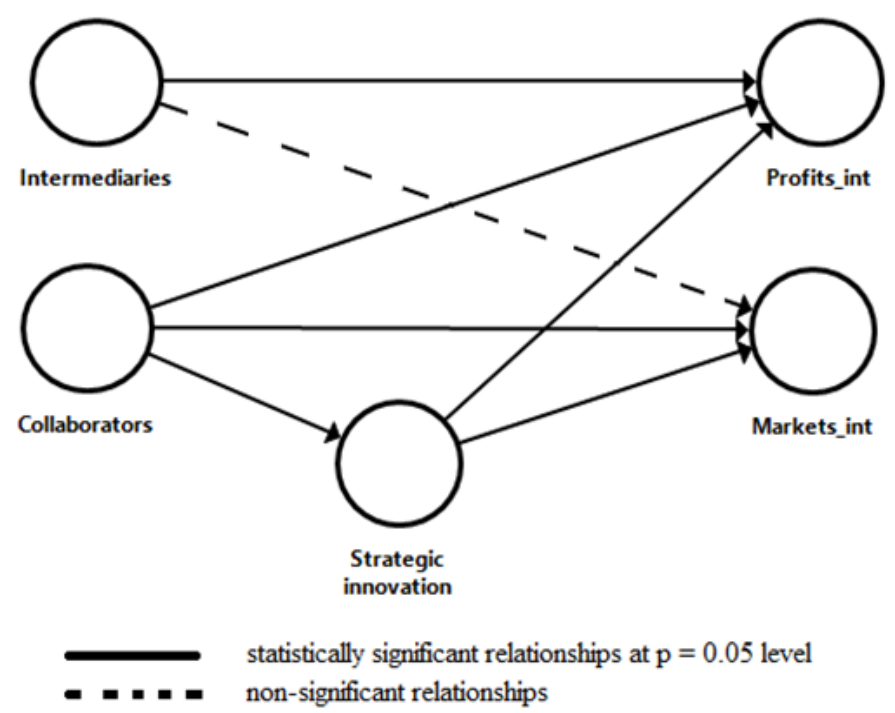

Figure 2. Significant relationships

Source: Authors 


\section{Results}

A first regression analysis (Table 2) assessed the variation of strategic innovation in relation to SMEs' tendency of developing direct collaborations with strategic partners on the external markets.

The results of the regression analysis performed to test the effects of Collaborators independent variable on the dependent variable Strategic innovation indicated a statistically significant prediction model $(\mathrm{F}=18.330, \mathrm{p}<0.05)$, with $15.5 \%$ of Strategic innovation variability $(\mathrm{R}$ Square $=0.155$ ) explained by the positive effect of Collaborators $(\beta$ $=0.394 ; \mathrm{t}=4.281 ; \mathrm{p}<0.001$, out of zero confidence intervals 95\% C.I. [0.229, 0. .645] based on 1000 bootstrap samples).

As expected, the positive effect of Collaborators on Strategic innovation, indicates that direct collaborations development with strategic partners operating on the external markets increases SMEs' innovative capability, thus supporting $\mathrm{H} 3$.

Table 2. Results of regression analysis (dependent variable Strategic innovation)

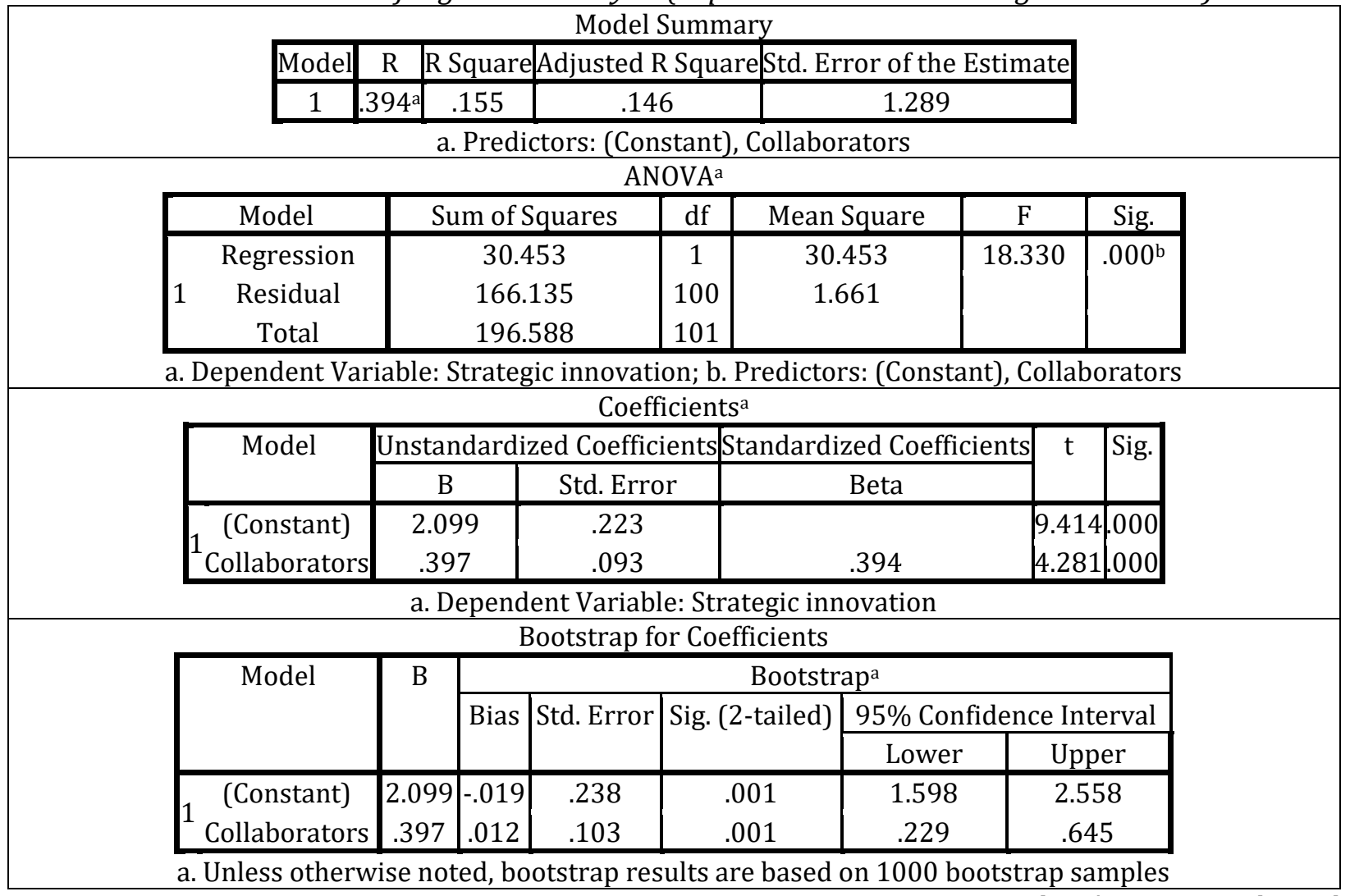

Source: Authors' own research results

A second and a third regression analyses were used to assess the influences exerted by Intermediaries, Collaborators, and Strategic Innovation variables on the SMEs' development on international markets (Markets_int dependent variable) and the proportion of SMEs' profitability resulted from international operations (Profits_int dependent variable).

Hence, the second regression analysis assessed SMEs' development on international markets considering the number of foreign markets where the organization is present 
(Markets_int) as dependent variable. The analysis (Table 3) used the independent variables Intermediaries, Collaborators and Strategic Innovation to assess their relationship with the number of foreign markets where the organization is present (Markets_int dependent variable). The results of the analysis detailed in Table 3 revealed a statistically significant prediction model $(\mathrm{F}=19.686, \mathrm{p}<0.05)$, explaining $37.6 \%$ of Markets_int variability ( $\mathrm{R}$ Square $=0.376$ ) through the high positive effect of Collaborators on Markets_int $(\beta=0.486$; $\mathrm{t}$ $=5.556$; significant at $\mathrm{p}<0.001$, out of zero confidence intervals 95\% C.I. [0.422, 0.998] based on 1000 bootstrap samples) and the positive effect of Strategic Innovation on Markets_int $(\beta=0.218 ; \mathrm{t}=2.475 ; \mathrm{p}=0.015$, significant at $\mathrm{p}<0.05$, out of zero confidence intervals $95 \% \mathrm{CI}[0.009,0.619]$ based on 1000 bootstrap samples). Therefore, $\mathrm{H} 1$ and $\mathrm{H} 4$ are supported by the empirical evidence.

The path coefficients $(\beta)$ and their statistical significance detailed in Table 3 have shown a non-significant effect of Intermediaries on Markets_int $(\beta=0.092 ; \mathrm{t}=1.128 ; \mathrm{p}=$ 0.262 , higher than 0.05 upper limit of statistical significance; zero value inside the confidence intervals $95 \%$ CI [ - 0.089, 0.316] resulted from bootstrapping). H6 is therefore not supported.

Table 3. Results of regression analysis (dependent variable: Markets_int)

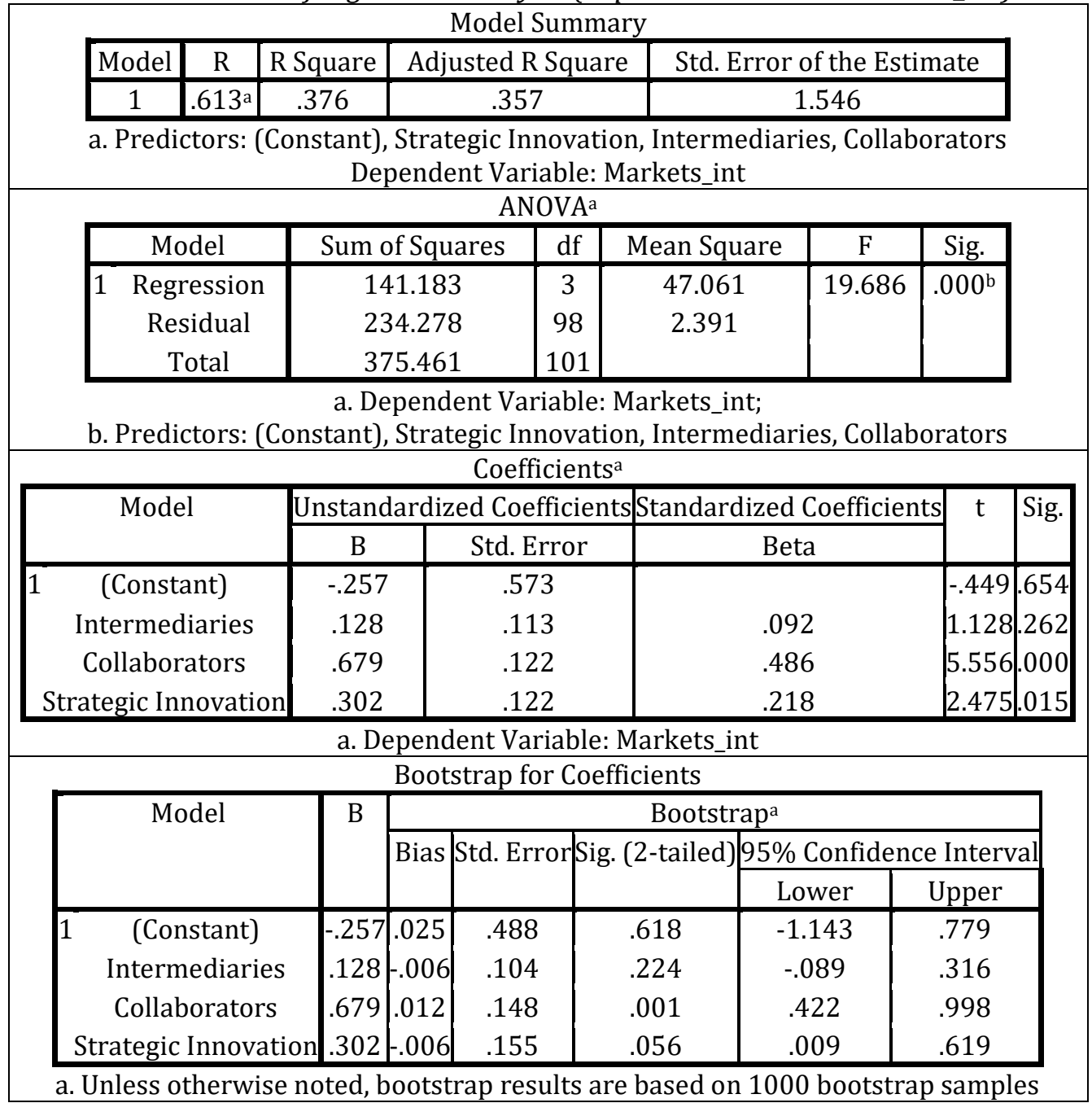


Table 4 presents the statistical outputs of the regression analysis assessing the proportion of SMEs' profits resulted from international operations, considering the dependent variable Profits_int, with the independent variables Intermediaries, Collaborators, and Strategic Innovation. As resulted from the analysis using as dependent variable Profits_int (the proportion of SMEs' profits resulted from international operations), the independent variables Intermediaries, Collaborators, and Strategic Innovation explain $42.9 \%$ of the dependent variable's variability (R Square $=0.429$ ), predicting the profitability achieved through international operations at a statistically significant level $(\mathrm{F}=24.558, \mathrm{p}<$ 0.05).

Moreover, the regression path coefficients $(\beta)$ and their statistical significance $(\mathrm{t}$ statistics and $\mathrm{p}$ values) detailed in Table 4 indicate a significant effect for each of the three independent variables Intermediaries $(\beta=0.224 ; \mathrm{t}=2.877 ; \mathrm{p}=0.005$; out of zero confidence intervals 95\% C.I. [.121, .407] based on 1000 bootstrap samples), Collaborators ( $\beta=0.258$; $\mathrm{t}$ $=3.085 ; \mathrm{p}=0.003$; out of zero confidence intervals 95\% C.I. [0.129, 0.537]), and Strategic Innovation $(\beta=0.448 ; t=5.314 ; \mathrm{p}<0.001$; out of zero confidence intervals $95 \%$ C.I. [0.312, $0.738]$ ) on the profitability achieved through international operations.

Table 4. Results of regression analysis (dependent variable: Profits_int)

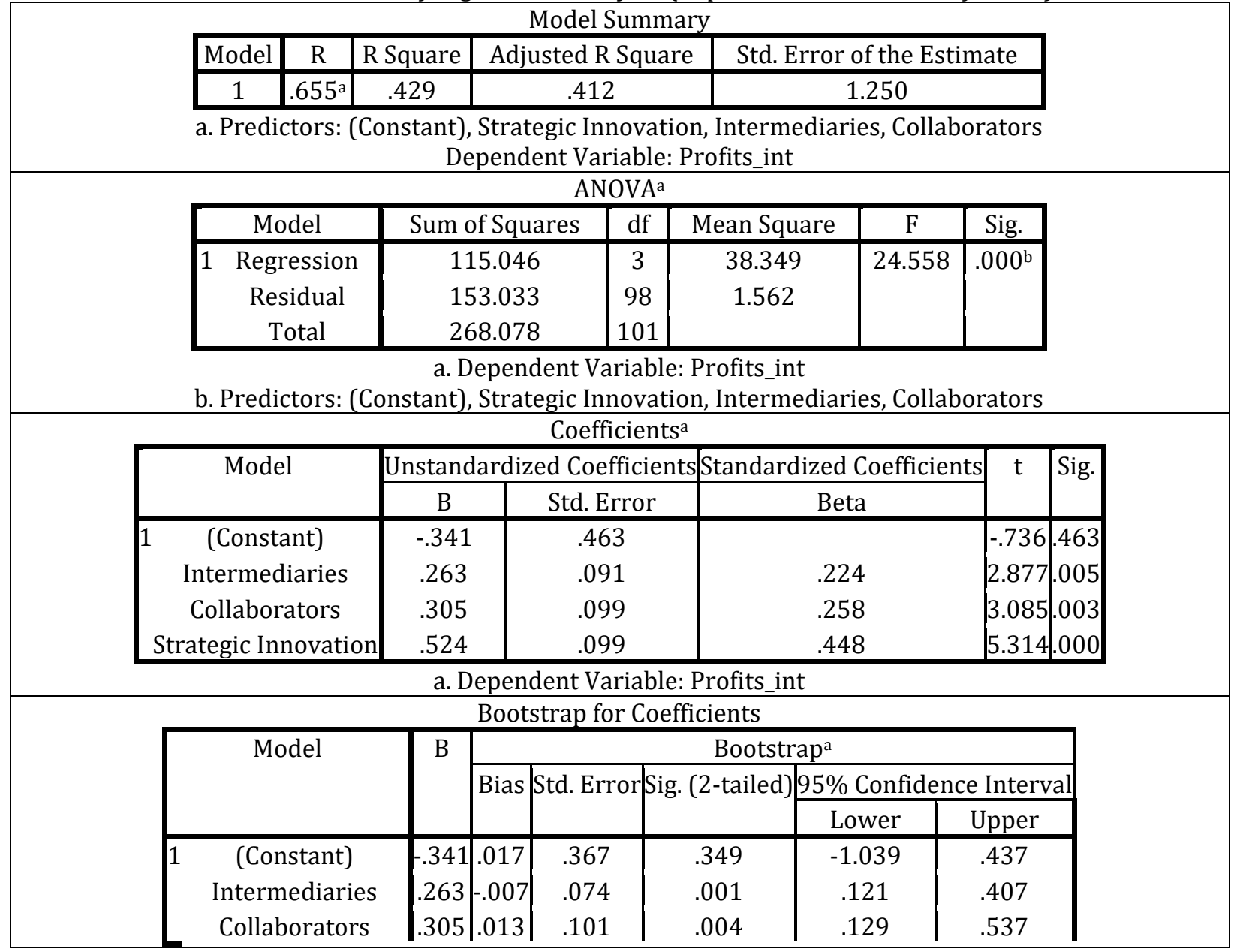




\begin{tabular}{|c|c|c|c|c|c|}
\hline & \begin{tabular}{|l|l|} 
Strategic Innovation $.524-.004$ \\
\end{tabular} & .110 & .001 & .312 & .738 \\
\hline
\end{tabular}

Source: Authors' own research results

In a nutshell, Intermediaries, Collaborators and Strategic Innovation have significant positive contributions to the profitability achieved through international operations (Profits_int) as follows: the Intermediaries variable exerts the lowest influence on Profits_int, direct strategic collaborations with specific partners operating on the external markets (Collaborators) exerts an increased influence, and the Strategic innovation has the highest impact on the proportion of SMEs' profitability resulted from international operations. Hence, H2, H5 and $\mathrm{H} 7$ are all supported by the data.

\section{Discussion and conclusions}

Summary of the findings

Overall, the results of the statistical analysis have shown the positive and significant relationship between collaborators and strategic innovation indicating that direct collaborations development with strategic partners operating on the external markets increase SMEs' innovative capability. The main facilitator in this front is the knowledge sharing process among strategic collaborators, which is fostered via strong social and business relationships, catalyzed within network structures and in the long run. These findings complement previous studies tackling the importance of strategic collaborators and strategic innovation (Miller and Friesen, 1982; Möller and Rajala, 2007; Iturrioz, Aragon \& Narvaiza, 2015; Vătămănescu \& Alexandru, 2018; Alexandru et al., 2020; Vătămănescu et al., 2019b, 2020b).

Another paramount evidence brought forward by the empirical research refers to the positive and high effects of direct collaborations with strategic partners operating on the foreign markets on the SMEs' development on external markets, and profitability achieved through international operations. Furthermore, the results indicated the positive effects of Strategic innovation on the SMES' development on the foreign markets and profitability from international operations. These corroborated findings echo previous studies contending the key role of strategic collaborators in SMEs internationalization from different interconnected perspectives (i.e., achieving innovative outcomes, profitability and expansion on more foreign markets), all of them indicative of how the sustainable competitive advantage could be achieved via knowledge-based international ventures (Varis et al., 2005; Capik and Brockerhoff, 2017; Vătămănescu et al., 2016b; 2017; Abrahamsen et al., 2016; Vătămănescu \& Alexandru, 2018; Keszey, 2018; Castela et al., 2018; Jordão, Novas and Gupta, 2019; Vătămănescu et al., 2019a,b).

Regarding the contribution of intermediaries as facilitators of SMEs' international ventures, the results revealed that Intermediaries had a statistically significant influence solely on the profitability. Profitability was positively influenced at a statistically significant level by each of the analyzed predictors: Intermediaries, Collaborators and Strategic Innovation. As regression path coefficients values indicated, intermediaries had the lowest influence on profitability. The relationships between the role of intermediaries and the profitability achieved through international operations is yet to be studied as the current discussions on the topic (Vătămănescu et al., 2019b; Apaydin, 2020) would benefit from 
further elaboration to thoroughly affirm their crucial importance in SMEs internationalization process.

\section{Research originality and implications}

By means of the proposed perspective, the present study may provide a reference point for both scholars and practitioners.

On the one hand, the exploration of the key knowledge-based antecedents of SMEs' international ventures - i.e., strategic collaborators, intermediaries and strategic innovation -, the investigation managed to connect the dots, as numerous previous endeavors had approached separate factors. Placing direct collaborations and the usage of intermediaries under the same lens allowed the simultaneous assessment of their influence on internationalization facets, namely expansion and profitability. The findings contribute to a better understanding on how knowledge capitalization within networks and partnerships is able to stimulate important outcomes, offering researchers food for thought in what concerns the relationship between collaborative knowledge sharing, profitability and development via international ventures.

On the other hand, the study has clear managerial implications. It highlights a strategic view on how SMEs managers should approach the internationalization process in an effective manner. The right strategy choice between direct collaborators and intermediaries, for example, can make a difference in the measurable outcomes, that is profitability and success of the development on foreign markets. Also, the paper proposed further insights into the effects exerted by direct collaborators and intermediaries via strategic innovation on the latent variables, thus aggregating interconnected dimensions within the same framework.

\section{Research limitations and further avenues}

Firstly, the investigation focuses only on several knowledge-based antecedents of SMEs' profitability and development via international ventures, namely strategic direct collaborators, intermediaries and strategic innovation. Future studies may also include different types of knowledge sharing (i.e., rational, emotional or spiritual) to touch more the intangible interchanges between individual and organizational actors.

Secondly, the empirical scrutiny revolves around a specific industrial field, the findings being indicative of this professional domain. Future undertakings would thus benefit from tackling other fields of interest to account for varied influences among the proposed variables.

Thirdly, the exploratory nature of the study invites future confirmatory analyses, which may approach the inferred relationships in-depth and develop more complex scales to assess each factor.

\section{Acknowledgement}

This work was supported by a grant of the Romanian Ministry of Education and Research, CNCS - UEFISCDI, project number PN-III-P1-1.1-TE-2019-1356, within PNCDI III. 


\section{References}

Abrahamsen, M.H., Henneberg, S.C., \& Huemer L. (2016). Network picturing: An action research study of strategizing in business networks. Review article. Industrial Marketing Management, 59, 107-119.

Alexandru, V.-A., Andrei, A.G., Bolisani, E., Cegarra Navarro, J.G., Martinez-Martinez, A., Paiola, M., Scarso, E., Vătămănescu, E.-M., and Zieba, M. (2020). Knowledge Management approaches of small and medium-sized firms: a cluster analysis. Kybernetes, 49(1), 73-87.

Andrade Rojas, M.G., Ramirez Solis, E.R., \& JianJun Zhu, J. (2018). Innovation and network multiplexity: R\&D and the concurrent effects of two collaboration networks in an emerging economy. Research Policy, 47, 1111-1124.

Andrei, A.G., \& Zaiț, A. (2014). Branding insights: an interdisciplinary journey from perception to action. In Bratianu, C., Zbuchea, A., Pinzaru, F., \& Vătămănescu, E.-M. (Eds.) Strategica: Management, Finance, and Ethics (pp. 593-604). Bucharest: Tritonic.

Apaydin, M., Thornberry, J., \& Sidani, Y.M. (2020). Informal Social Networks as Intermediaries in Foreign Markets. Management and Organization Review, 16(3), 629-656.

Bell, J., McNaughton, R., Young, S., \& Crick, D. (2003). Towards an integrative model of small firm internationalization. Journal of International Entrepreneurship, 1(4), 339-362.

Boon, W.P., Moors, E.H., Kuhlmann, S., \& Smits, R.E. (2011). Demand articulation in emerging technologies: intermediary user organisations as co-producers? Research Policy, 40, 242-252.

Bratianu, C., Hadad, S., \& Bejinaru, R. (2020). Paradigm shift in business education: a competence-based approach. Sustainability, 12(4), 1348, 1-17.

Bratianu, C., Nestian, A.S., Tita, S.M., Voda, A.I., \& Guta, A.L. (2020). The impact of knowledge risk on sustainability of firms. Amfiteatru Economic, 22(55), 639-652.

Bratianu, C., Prelipcean, G., \& Bejinaru, R. (2020). Exploring the latent variables which support SMEs to become learning organizations. Management \& Marketing. Challenges for the Knowledge Society, 15(2), 154-171.

Bratianu, C., Vătămănescu, E.-M., Anagnoste, S., \& Dominici, G. (2021). Untangling knowledge fields and knowledge dynamics within the decision-making process. Management Decision, 59(2), 306-323.

Bustinza, O., Gomes, E., Vendrell-Herrero, F., \& Baines, T. (2019). Product-service innovation and performance: the role of collaborative partnerships and R\&D intensity. R\&D Management, 49 (1), 33-45.

Capik, P., \& Brockerhoff, A. (2017). The Role of Strategic Partnerships in the Internationalisation of Small Born Global Firms. Entrepreneurial Business and Economics Review, 5(3), 49-77.

Castela, B.M.S., Ferreira, F.A.F., Ferreira, J.J.M., \& Marques, C.S.E. (2018). Assessing the innovation capability of small and medium-sized enterprises using a non-parametric and integrative approach. Management Decision, 56(6), 1365-1383.

Cavusgil, S.T., \& Knight, G. (2009). Born Global Firms: A New International Enterprise. New York: Business Expert Press. 
Cefis, E., \& Ciccarelli, M. (2005). Profit differentials and innovation. Economics of Innovation and New Technology, 14, 43-61.

Cegarra-Navarro, J.G., Vătămănescu, E.-M., \& Martínez-Martínez, A. (2021). A context-driven approach on coping with COVID-19: From hiding knowledge toward citizen engagement. Knowledge and Process Management, 28(2), 134-140.

Comi, A., \& Eppler, M.J. (2009). Building and Managing Strategic Alliances in TechnologyDriven Start-Ups: A Critical Review of Literature. Lugano: Institute of Marketing and Communication Management (IMCA)

Dekel-Sachs, O. et al. (2021) Searching for a new perspective on institutional voids, networks and the internationalisation of SMEs in emerging economies: a systematic literature review. International Marketing Review, Vol. ahead-of-print No. ahead-ofprint.

Demirbag, M., Apaydin, M., \& Sahadev, S. (2021). Micro-foundational dimensions of firm internationalisation as determinants of knowledge management strategy: A case for global strategic partnerships. Technological Forecasting and Social Change, 165(3).

De Silva, M., Howell, J., \& Meyera, M. (2018). Innovation intermediaries and collaboration: Knowledge-based practices and internal value creation. Research Policy, 47, 70-87.

Dima, A.M., Ghinea, V. M. (2016). A model of Academic Leadership, Conference: 12th European Conference on Management, Leadership and Governance (ECMLG) Location: Natl Univ Polit Studies \& Publ Adm, Coll Management, Bucharest, ROMANIA. Proceedings of the Conference on European Management Leadership and Governance, pp. 61-70.

Dima, M.A., Vasilache, S. (2009). ANN Model for Corporate Credit Risk Assessment, 2009 International Association of Computer Science and Information Technology Spring Conference (IACSIT-SC 2009), International Conference on Information and Financial Engineering (ICIFE2009), Singapore, 17-19 April, ISSN 976-07695-3653-8.

Dima, A.M, Vasilache, S. (2015). Social Network Analysis for Tacit Knowledge Management in Universities. Journal of the Knowledge Economy. 6(4). pp. 856-864.

Dolfsma, W., \& van der Eijk, R. (2016). Network position and firm performance - the mediating role of innovation. Technology Analysis \& Strategic Management, 29(6), 556-568.

Earl, M. (2001). Knowledge management strategies: toward a taxonomy. Journal of Management Information Systems. 18, 215-233.

Edler, J., \& Yeow, J. (2016). Connecting demand and supply: The role of intermediation in public procurement of innovation. Research Policy, 45(2), 414-426.

Efrata, K., \& Øynab, S. (2020). An interaction orientation approach to SME-Intermediaries relationships. European Management Journal, 24 October 2020.

Elmuti, D., \& Kathawala, Y. (2001). An overview of strategic alliances. Management Decision, $39(3), 205-217$.

European Commission (2021). Euro area international trade in goods surplus €6.3 bn. Retrieved from https://ec.europa.eu/eurostat/documents/2995521/11562995/618032021-BP-EN.pdf.

Frazier, G., Maltz, E., Antia, K., \& Rindflesch, A. (2009). Distributor Sharing of Strategic Information with Suppliers. Journal of Marketing, 73(1), 31-43. 
Fredrich, V., Bouncken, R.B., \& Kraus, S. (2019). The race is on: Configurations of absorptive capacity, interdependence and slack resources for interorganizational learning in coopetition alliances. Journal of Business Research, 10, 862-868.

Geroski, P., Machin, S., \& Van Reenen, J. (1993). The profitability of innovating firms. The RAND Journal of Economics, 24, 198-211.

Geroski, P., Van Reenen, J., \& Walters, C.F. (1997). How persistently do firms innovate?. Research Policy, 26, 33-48.

Giannacourou, M., Kantaraki, M., \& Christopoulou, V. (2015). The Perception of Crisis by Greek SMEs and Its Impact on Managerial Practices. Procedia - Social and Behavioral Sciences, 175, 546-551.

Gomezel, A.S., \& Rangus, K. (2018). An exploration of an entrepreneur's open innovation mindset in an emerging country. Management Decision, 56(9), 1869-1882.

Håkansson, H., Ford, D., Gadde, L.-E., Snehota, I., \& Waluszewski, A. (2009). Business in Networks. Chichester: John Wiley \& Sons.

Hanel, P., \& St-Pierre, A. (2002). Effects of R\&D spillovers on the profitability of firms. Review of Industrial Organization, 20, 305-322.

Hossain, I., Azam, S., \& Quaddus, M. (2021). Small firm entry to e-marketplace for market expansion and internationalization: A theoretical perspective. Journal of International Entrepreneurship.

Howells, J. (2006). Intermediation and the role of intermediaries in innovation. Research Policy, 35, 715-728.

Huizingh, E.K. (2011). Open innovation: state of the art and future perspectives. Technovation, 31, 2-9.

Iturrioz, C., Aragon, C., \& Narvaiza, L. (2015). How to foster shared innovation within SMEs networks: social capital and the role of intermediaries. European Management Journal, 33, 104-115.

Johanson, J., \& Vahlne, J. (2009). The Uppsala internationalization process model revisited: From liability of Foreignness to Liability of Outsidership. Journal of International Business Studies, 40(9), 1411-1431.

Jordão, R.V.D., Novas, J., \& Gupta, V. (2019). The role of knowledge-based networks in the intellectual capital and organizational performance of small and medium-sized enterprises. Kybernetes, 49(1), 116-140.

Keszey, T. (2018). Boundary spanners' knowledge sharing for innovation success in turbulent times. Journal of Knowledge Management, 22(5), 1061-1081.

Klein, V.B., \& Todesco, J.L. (2021). COVID-19 crisis and SMEs responses: The role of digital transformation. Knowledge and Process Management, 1-17.

Klerkx, L., \& Leeuwis, C. (2008a). Matching demand and supply in the agricultural knowledge infrastructure: experiences with innovation intermediaries. Food Policy, $33,260-276$.

Klerkx, L., \& Leeuwis, C. (2008b). Balancing multiple interests: embedding innovation intermediation in the agricultural knowledge infrastructure. Technovation, 28, 364378.

Knockaert, M., \& Spithoven, A. (2014). Under which conditions do technology intermediaries enhance firms' innovation speed? The case of Belgium's Collective Research Centres. Regional Studies, 48, 1391-1403. 
Landry, R., Amara, N., Cloutier, J.S., \& Halilem, N. (2013). Technology transfer organizations: services and business models. Technovation, 33, 431-449.

Leiponen, A. (2000). Competencies, innovation and profitability of firms. Economics of Innovation and New Technology, 9, 1-24.

Li, P. P., Zhou, S. S., Zhou, A. J., \& Yang, Z. (2019). Reconceptualizing and redirecting research on guanxi: 'guan-xi' interaction to form a multicolored Chinese knot. Management and Organization Review, 15(3), 643-677.

Lichtenthaler, U., \& Ernst, H. (2008). Intermediary services in the markets for technology: organizational antecedents and performance consequences. Organization Studies, 29, 1003-1035.

Lichtenthaler, U. (2013). The collaboration of innovation intermediaries and manufacturing firms in the markets for technology. Journal of Product Innovation Management, 30, 142-158.

Love, J.H., Roper, S., \& Du, J. (2009). Innovation, ownership and profitability. International Journal of Industrial Organization, 27, 424-434.

Luostarinen, R., \& Gabrielsson, M. (2006). Globalization and marketing strategies of born globals in SMOPECs. Thunderbird International Business Review, 48(6), 773-801.

Luo, Y. (2007). A coopetition perspective of global competition. Journal of World Business, $42(2), 129-144$.

Małys, Ł., \& Fonfara, K. (2019). From Intermediary Relationship to Multiple Relationships Option of Developing the Network Position in the Internationalisation Process. An Exploratory Study of a Polish Food Company. Olsztyn Economic Journal, 14(2), 209221.

Martín-de Castro, G. (2015). Knowledge management and innovation in knowledge-based and high-tech industrial markets: the role of openness and absorptive capacity. Industrial Marketing Management, 47, 143-146.

Melle, C., \& Russo-Spena, T. (2015). Innomediary agency and practices in shaping market innovation. Industrial Marketing Management, 44, 42-53.

Miller, D., \& Friesen, P. (1982). Innovation in conservative and entrepreneurial firms: two models of strategic momentum. Strategic Management Journal, 3(1), 1-25.

Möller, K., \& Rajala, R. (2007). Rise of strategic nets - New modes of value creation. Industial Marketing Management, 36, 895-908.

Morgan, R.M., \& Hunt, S.D. (1994). The Commitment-Trust Theory of Relationship Marketing. Journal of Marketing, 58(3), 20-38.

Nell, P.S.V., \& Lichtenthaler, U. (2011). The role of innovation intermediaries in the markets for technology. International Journal of Technology Intelligence and Planning, 7(2), 128-139.

Nguyen, H.T., \& Le, V. (2019). Network ties and export propensity of Vietnamese small and medium enterprises. Asia Pacific Business Review, 25(1), 100-122.

Nistoreanu, P., Dincă, V.M., \& Șchiopu, A.F. (2017). Competition Policy in the European Film Industry Focused on Consumers' Interests - a Romanian Perspective. Amfiteatru Economic, 19(45), 397-413.

Prashantham, S., Zhou, A. J., \& Dhanaraj, C. (2020). Depth vs. breadth: Network strategy in emerging markets. Management and Organization Review, 16(2): 229-260. 
Quintana-García, C., \& Benavides-Velasco, C. A. (2004). Cooperation, competition, and innovative capability: A panel data of European dedicated biotechnology firms. Technovation, 24, 927-938.

Raposo, M.L., Ferreira, J.J.M., \& Fernandes, C.I. (2014). Local and cross-border SME cooperation: effects on innovation and performance. Revista Europea de Direccion y Economia de la Empresa, 23, 157-165.

Raza-Ullah, T., \& Eriksson, J. (2017). Knowledge Sharing and Knowledge Leakage in Dyadic Coopetitive Alliances Involving SMEs. In Sindakis, S., Theodorou, P. (Eds.). Global Opportunities for Entrepreneurial Growth: Coopetition and Knowledge Dynamics within and across Firms (Advanced Strategies in Entrepreneurship, Education and Ecology) (pp. 229-252). England, UK: Emerald Publishing Limited.

Roberts, P.W. (1999). Product innovation, product-market competition and persistent profitability in the US pharmaceutical industry. Strategic Management Journal, 20, 655-670.

Sampson, R.C. (2007). R\&D alliances and firm performance: the impact of technological diversity and alliance organization on innovation. The Academy of Management Journal, 50(2), 364-386.

Senik, Z.C., Scott-Ladd, B., Entrekin, L., \& Adham, K. (2011). Networking and internationalization of SMEs in emerging economies. Journal of International Entrepreneurship, 9(4), 259-281.

Sieg, J.H., Wallin, M.W., \& von Krogh, G. (2010). Managerial challenges in open innovation: a study of innovation intermediation in the chemical industry. $R$ \& D Management, 40 (3), 281-291.

Sindakis, S., Aggarwal, S., \& Theodorou, P. (2017). Coopetition and Knowledge Dynamics: Knowledge Creation and Management for Growth. In Sindakis, S., Theodorou, P. (Eds.), Global Opportunities for Entrepreneurial Growth: Coopetition and Knowledge Dynamics wihin and across Firms (Advanced Strategies in Entrepreneurship, Education and Ecology) (pp. 165-185), England, UK: Emerald Publishing Limited.

Sindakis, S., Aggarwal, S., \& Chen, C. (2019). Coopetitive dynamics and inter-organizational knowledge flow among venture capital firms: A systematic literature review. Kybernetes, 49(1), 47-72.

Smedlund, A., (2006). The roles of intermediaries in regional knowledge systems. Journal of Intellectual Capital, 7, 204-222.

Soto-Acosta, P., Cismaru, D.-M., Vătămănescu, E.-M., \& Ciochină, R.S. (2016). Sustainable Entrepreneurship in SMEs: A Business Performance Perspective. Sustainability, 8(4), Art. 342.

Swoboda, B., Pop, N.A., \& Dabija, D.C. (2010). Vertical Alliances between Retail and Manufacturer Companies in the Fashion Industry. Amfiteatru Economic, 12(28), 634649.

Swoboda, B., Meierer, M., Foscht, T., \& Morschett, D. (2011). International SME Alliances: The Impact of Alliance Building and Configurational Fit on Success. Long Range Planning, 44(4), 271-288.

Tran, Y., Hsuan, J., \& Mahnke, V. (2011). How do innovation intermediaries add value? Insight from new product development in fashion markets. $R \& D$ Management, 41, 80-91. 
Van Gils, A., \& Zwart, P.S. (2009). Alliance Formation Motives in SMEs: An Explorative Conjoint Analysis Study. International Small Business Journal, 27(1), 5-37.

Varis, J., Kuivalainen, 0., \& Saarenketo, S. (2005). Partner Selection for International Marketing and Distribution in Corporate New Ventures. Journal of International Entrepreneurship, 3(1), 19-36.

Vătămănescu, E.-M., Alexandru, V.-A., \& Gorgos, E.-A. (2014). The Five Cs Model of Business Internationalization (CMBI) - a preliminary theoretical insight into today's business internationalization challenges. In Brătianu, C., Zbuchea, A., Pînzaru, F., \& Vătămănescu, E.-M. (Eds.), Strategica. Management, Finance, and Ethics (pp. 537558). Bucharest: Tritonic.

Vătămănescu E.-M., Alexandru, V.-A., \& Andrei A.G. (2015). The relational leader. A preliminary framework for corporate intercultural accommodation. In Brătianu, C., Zbuchea, A., Pînzaru, F., Vătămănescu, E.-M., \& Leon, R.D. (Eds.), Strategica. Local versus Global (pp. 303-312). Bucharest: Tritonic.

Vătămănescu E.-M., Zbuchea, A., Pînzaru, F., \& Andrei, A.G. (2016a). The Impact of Relational Capital on SME Internationalization. Leveraging Online Versus Offline Business Networking. In Moffett, S., \& Galbraith, B. (Eds.), Proceedings of the 17th European Conference on Knowledge Management (pp. 926-935). Reading, UK: Academic Conferences and Publishing International Limited.

Vătămănescu, E.-M., Pînzaru, F., Andrei, A.G., \& Zbuchea, A. (2016b). Investigating SMEs sustainability with partial least squares structural equation modeling. Transformations in Business \& Economics (TIBE), 15(3), 259-273.

Vătămănescu, E.-M., Andrei, A.G., Nicolescu, L., Pînzaru, F., \& Zbuchea, A. (2017). The Influence of Competitiveness on SMEs Internationalization Effectiveness. Online versus Offline Business Networking. Information Systems Management, 34(3), 205219. Retrieved from http://www.tandfonline.com/doi/full/10.1080/10580530.2017.1329997

Vătămănescu E.-M., Gorgos, E.-A., \& Alexandru, V.-A. (2018). Preliminary Insights into SMEs Opportunities and Vulnerabilities in the European Context. A Qualitative Approach. Management Dynamics in the Knowledge Economy, 6(3), 385-404.

Vătămănescu E.-M., \& Alexandru, V.-A. (2018). Beyond Innovation: The Crazy New World of Industrial Mash-ups. In Vătămănescu, E.-M., \& Pînzaru, F. (Eds.), Knowledge Management in the Sharing Economy - Cross-Sectoral Insights into the Future of Competitive Advantage (pp. 271-285). Cham: Springer International Publishing.

Vătămănescu, E.-M., \& Mitan, A. (2019). From In-House towards International Contexts. An Insight into Romanian SMEs Internationalization. In Bratianu, C., Zbuchea, A., Hrib, B., Vițelar, A., \& Anghel, F. (Eds.), Strategica. Upscaling Digital Transformation in Business and Economics (pp. 503-513). Bucharest: Tritonic

Vătămănescu, E.-M., Gorgos, E.-A., Ghigiu, A.M., \& Pătruț, M. (2019a). Bridging Intellectual Capital and SMEs Internationalization through the Lens of Sustainable Competitive Advantage: A Systematic Literature Review. Sustainability, 11(9), 2510.

Vătămănescu, E.-M., Dincă, V.-M., Andrei, A.G., \& Alexandru, V.-A. (2019b). Strategic Networks and Innovative Performance: a Relational Design of Knowledge Sharing in Small and Medium-Sized Enterprises. In Schiuma, G., Demartini, P., \& Yan, M.-R. (Eds.), Proceedings IFKAD 2019. Knowledge Ecosystems and Growth (pp. 2084-2094). Matera: Institute of Knowledge Asset Management. 
Vătămănescu, E.-M., Alexandru, V.-A., Gorgos, E.-A., \& Mitan, A. (2020a). Filling the Gaps. Intellectual Capital and the Internationalization of European SMEs. Saarbrucken: Lambert Academic Publishing.

Vătămănescu, E.-M., Cegarra-Navarro, J.-G., Andrei, A.G., Dincă, V.-M. and Alexandru, V.-A. (2020b). SMEs strategic networks and innovative performance: a relational design and methodology for knowledge sharing. Journal of Knowledge Management, 24(6), 1369-1392.

Vătămănescu, E.-M., Alexandru, V.-A., Mitan, A., \& Dabija, D.-C. (2020c). From the deliberate managerial strategy towards international business performance: A psychic distance vs. global mindset approach. Systems Research and Behavioral Science, 37(2), 374387.

Vătămănescu, E.-M., Mitan, A., Dincă, V.M., \& Andrei, A.G. (2020d). Integrating intellectual capital and SMEs internationalization into a common conceptual framework. In Bratianu, C., Zbuchea, A., Anghel, F., \& Hrib, B. (Eds.), STRATEGICA. Preparing for Tomorrow, Today (pp. 792-805). Tritonic: Bucharest.

Vătămănescu, E.-M., Mitan, A., Andrei, A.G., \& Ghigiu, A.M. (2021). Linking coopetition benefits and innovative performance within small and medium-sized enterprises networks: a strategic approach on knowledge sharing and direct collaboration. Kybernetes, Ahead-of-print.

Wassmer, U. (2010), Alliance Portfolios: A Review and Research Agenda. Journal of Management, 36(1), 141-171.

World Bank Group (2020). Trading for Development in the age of global value chains world development report. Retrieved from https://openknowledge.worldbank.org/handle/10986/32437

Zeng, S.X., Xie, X.M., \& Tam, C.M. (2010), Relationship between cooperation networks and innovation performance of SMEs. Technovation, 30(3), 181-194. 